\title{
Field Monitoring of Cypermethrin Residual Effect on the Mortality Rates of the Phlebotomine Sand Fly Lutzomyia longipalpis in the State of Paraíba, Brazil
}

\author{
Laura Ney Marcelino Passerat De Silans, Jean-Pierre Dedet ${ }^{*}$, \\ Jorge R Arias**
}

Fundação Nacional de Saúde da Paraíba, Rua Prof. Geraldo Von Shosten 285, 58015-000 João Pessoa, PB, Brasil *Laboratoire d'Ecologie Médicale et Pathologie Parasitaire, Faculté de Médecine, 163, rue Auguste Broussonnet, Montpellier 34090, France **OPS, Setor Embaixadas Norte, Lote 19, 70090-000 Brasília, DF, Brasil

In a visceral leishmaniasis endemic locality of northeast of Brasil where all settlements were treated with cypermethrin, a follow-up of Lutzomyia longipalpis populations was carried out by regular collections. The residual effect of the insecticide was studied using biological assays on three different types of walls.

The results showed that the insecticides had an effect on intradomiciliar Lu. longipalpis populations limited to two months, and had no significant effect on peridomiciliar vector populations. The mortality rates of the tested sandflies were variable according to the type of wall.

The decreasing of the insecticide effect was marked since the 3rd month, and mortality rates were identical whatever the type of wall since the 4th month. Unsufficient residual effect was detected after the 4th month.

Key words: visceral leishmaniasis - sand flies - control - insecticides - pyrethroids - cypermethrin

Residual insecticide indoor and outdoor spraying is a commonly used technique for obtaining a reduction of vector-man contact, during leishmaniasis control programmes in endemic foci.

Several authors have reported that residual insecticide spraying reduces sand fly density and therefore leishmaniasis transmission, in various localities in Africa (Coradetti 1968, Büttiker 1980, Mutinga \& Kamau 1986), India (Mukhopadhyay et al. 1992, Kaushal et al. 1995), China (Xiong Guang-Hua \& Jin Chang 1987) and South America (Le Pont et al 1989, Falcão et al. 1991, Oliveira Filho \& Melo 1994).

Similarily, the observation of the increase of human leishmaniasis following the interruption of DDT spraying due to the decline of malaria control programmes in various countries, confirms the role played by residual insecticides in the control of vector borne diseases (Lane 1990).

In Brazil, chemical control of Lutzomyia longipalpis and the elimination of infected dogs are two of the principal measures of the Visceral Leishmaniasis Control Programme (VLCP) developed since 1970 by the Ministry of Health.

\footnotetext{
${ }^{+}$Corresponding author. Fax : +33-4-67-63.0049

Received 14 October 1997

Accepted 2 March 1998
}

Alternative methods for individual protection are actively investigated. Insecticide impregnated bed nets and screens, body repelents and pheromone baits already used against Anopheles and Glossina are being tried against phlebotomine sand flies.

At the present time, indoor insecticide spraying is the main entomological activity used during leishmaniasis control programmes. In this context, epidemiological impact and real residual effect of the insecticides used need to be investigated under field conditions within the biogeographical area treated.

A five month entomological follow up was carried out in an area sprayed with cypermethrin, in order to evaluate the efficacy of the insecticide on intra and peri-domiciliary populations of $L u$. longipalpis and to verify the residual effect of the insecticide.

\section{MATERIALS AND METHODS}

Due to high rates of VL transmission to humans in Caxitu St. (Conde municipality, south coastal of the State of Paraíba), a locality of 180 houses was treated with cypermethrin $31.2 \% \mathrm{WP}$ at a rate of $125 \mathrm{mg}$ a.i. $/ \mathrm{m}^{2}$. The insecticide was sprayed on the external and internal walls of houses, including appended rooms and animal dwellings (chicken coops, pigty, cow shed, etc.).

The entomological follow up was carried out 
during a five month period, and included the following evaluation techniques: (1) bioassays on cypermethrin treated walls (WHO 1970); (2) systematic sampling of sand fly populations in 50\% of the houses; an untreated neighbouring locality was used as a control (Pedreira St). Sand flies were collected by aspirators and CDC light traps.

Bioassays - The sand flies submitted to bioassays were collected with aspirators on animal bait, by peridomestic collections in Nossa Senhora das Neves locality (Conde municipality).

The bioassays technique was the same used and described in detail in Passerat de Silans and Dedet (1998). Briefly, the collected sand flies were transported in small cages to the laboratory, where they were fed on a 30\% sugar solution, and kept for 12 $\mathrm{hr}$ in order to check their viability. All tests began at 7 a.m. and included seven samples of 20 individuals each, placed in conical chambers at $1.5 \mathrm{~m}$ from ground floor. Four of the conical chambers were placed on sprayed walls in different rooms: sitting room, dining room, bed room and corridor, and the fifth chamber was placed on a wooden surface, generally a window. The sixth and seventh chambers were used as control, and were protected from the sprayed support by thick pieces of cardboard.

The sand flies were exposed to wall surfaces for $1 \mathrm{hr}$. They were then removed from the chambers, placed in plastic cups, fed on a sugar solution and observed for $24 \mathrm{hr}$. Their behaviour during the post-exposition time was noted and the count of dead and live flies was recorded.

Characteristics of the tested dwellings - The assays were carried out on three types of adobe wall dwellings, typical of those in VL endemic coastal area: (1) plastered with adobe (not painted) (FNS 86 dwelling); (2) rough adobe without plastering (FNS 84 dwelling), and (3) plastered with adobe and painted of lime base paint (FNS 15 dwelling).

One set of bioassays was carried out for each type of dwellings, each month, during five months. After the fifth month assay, the lack of mortality of sand flies did not justify the continuation of the assays.

During each assay, bioasssays were carried out on a wooden surface in the house, as control sample, since we have already shown that these wood surfaces have a very good residual effect when sprayed with pyrethroïds (Passerat de Silans 1991). In order to minimize the bias, and to avoid the modifications of the tested surface, we placed the conical chambers in parallel lines, at few centimeters from the previous tests.

Systematic sampling of sand fly collections Systematic sand fly collections were performed according to two methods: (1) with active manual collection in $50 \%$ of the dwellings of the locality, with systematic choice of a house out of two. A Castro buccal aspirator and a lamp were used for collection. Two collection sessions were performed every month; (2) with CDC light-traps, placed in five dwellings, one inside and a second in peridomiciliar position, in equidistant points of the locality. The light-traps were placed during four consecutive days, two weeks per month.

\section{RESULTS}

Wall bioassays - Several experiments showed the excellent residual effect of pyrethroïds on wooden surfaces, with $100 \%$ mortality rates for sand flies exposed to surfaces nine months after their spraying.

Assays in FNS 86 dwelling - Assays on adobe walls plastered with adobe showed satifactory percentages of mortality one month after the spraying (95\%); but this decreased progressively and rapidly during the following three months: $82.3 \%$, $56.7 \%$ and $36.2 \%$ for 2 nd, 3rd and 4th month respectively (Table). The residual activity of the insecticide five months after the spraying was only $3.8 \%$.

Assays in FNS 84 dwelling - In the rought adobe houses without plastering, the residual effect of the insecticide showed satisfactory rates during three months following spraying: $96 \%, 90 \%$ and $95 \%$ respectively. However, after the fourth month, the insecticide activity significantly decreased to $49 \%$ (Table).

Assays in FNS 15 dwelling (puddled clay roughcast and lime painted wall) - In those plastered with adobe and painted of lime base paint, mortality rates obtained the two first months after spraying were $72 \%$ and $61 \%$, inferior to the mortality rates obtained in the two other dwelling types tested. However, the mortality rates obtained for the 4th and 5 th months (62\% and 34\% respectively) were roughly similar to those obtained at the same time as in the other types of dwelling (Table).

In the three types of dwellings, the decrease of the residual activity of the insecticide was significant after the third and fourth month of spraying. The residual effect after the fourth month was similar for the three types of wall, with only a $10 \%$ difference from one dwelling type to another.

The results according to dwelling types are illustrated in Fig 1.

The mortality percentages of the samples exposed to wooden surfaces in the adobe walls plastered with adobe and plastered with adobe and painted of lime base paint dwellings were 100\% up to the fifth month. However in the case of rought adobe without plastering dwelling, there was a 
TABLE

Bioassays performed for evaluation of residual effect of $125 \mathrm{mg} \mathrm{a.i} / \mathrm{m}^{2}$ cypermethrin $31.2 \%$ on mortality of the phlebtomine Lutzomyia longipalpis, during five months in Caxitu St (Conde), in the State of Paraíba

\begin{tabular}{|c|c|c|c|c|c|c|c|c|c|}
\hline \multirow[t]{2}{*}{ Bioassays } & \multirow[t]{2}{*}{ Model of the wall surfaces } & \multirow{2}{*}{$\begin{array}{l}\text { Days after } \\
\text { spraying }\end{array}$} & \multicolumn{3}{|c|}{ Sandflies exposed to walls } & \multicolumn{2}{|c|}{ Sandlies exposed to wood } & \multicolumn{2}{|c|}{ Control } \\
\hline & & & Number & $\begin{array}{l}\% \text { mortality } \\
\text { after } 24 \mathrm{hr}\end{array}$ & $\begin{array}{c}\% \text { corrected } \\
\text { mortality }\end{array}$ & Number & $\begin{array}{c}\% \\
\text { mortality } \\
\text { after } 24 \mathrm{hr}\end{array}$ & Number & $\begin{array}{c}\% \\
\text { mortality } \\
\text { after } 24 \mathrm{hr}\end{array}$ \\
\hline 1 & Rought adobe without plastering & 40 & 80 & 96.2 & 95.4 & 20 & 100 & 40 & 13.8 \\
\hline 2 & Rought adobe without plastering & 72 & 79 & 82.3 & 80.0 & 20 & 100 & 40 & 12.5 \\
\hline 3 & Rought adobe without plastering & 107 & 74 & 56.7 & N/A & 20 & 100 & 40 & 0 \\
\hline 4 & Rought adobe without plastering & 143 & 80 & 36.2 & N/A & 11 & 91 & 39 & 2.5 \\
\hline 5 & Rought adobe without plastering & 178 & 80 & 3.7 & N/A & 20 & 55 & 40 & 0 \\
\hline 6 & Adobe walls plastered with adobe & 41 & 60 & 95.0 & N/A & 20 & 100 & 40 & 0 \\
\hline 7 & Adobe walls plastered with adobe & 74 & 80 & 90.0 & N/A & 20 & 100 & 40 & 0 \\
\hline 8 & Adobe walls plastered with adobe & 109 & 80 & 95.0 & N/A & 20 & 95 & 40 & 0 \\
\hline 9 & Adobe walls plastered with adobe & 145 & 78 & 46.2 & N/A & 20 & 100 & 40 & 2.5 \\
\hline 10 & $\begin{array}{l}\text { Adobe walls plastered with adobe } \\
\text { and painted with the based paint }\end{array}$ & 41 & 80 & 72.5 & N/A & 20 & 100 & 40 & 0 \\
\hline 11 & $\begin{array}{l}\text { Adobe walls plastered with adobe } \\
\text { and painted with the based paint }\end{array}$ & 73 & 65 & 61.5 & N/A & 15 & 100 & 31 & 0 \\
\hline 12 & $\begin{array}{l}\text { Adobe walls plastered with adobe } \\
\text { and painted with the based paint }\end{array}$ & 108 & 72 & 62.5 & N/A & 20 & 100 & 40 & 0 \\
\hline 13 & $\begin{array}{l}\text { Adobe walls plastered with adobe } \\
\text { and painted with the based paint }\end{array}$ & 144 & 78 & 34.6 & N/A & 20 & 100 & 40 & 0 \\
\hline 14 & $\begin{array}{l}\text { Adobe walls plastered with adobe } \\
\text { and painted with the based paint }\end{array}$ & 179 & 78 & 37.2 & N/A & 20 & 100 & 40 & 0 \\
\hline
\end{tabular}

$a$ : correction using Abbotts formula; N/A: not applicable. 
Results of wall bioassays with cypermethrin treatment

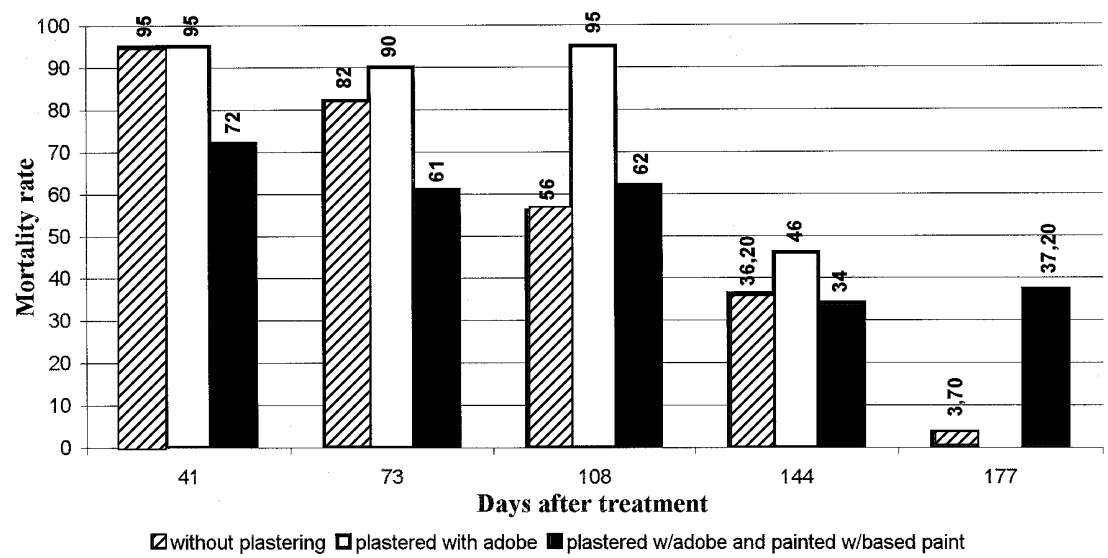

Fig. 1: results of mortality rates of Lutzomyia longipalpis in wall bioassays with cypermethrin treatment.

decrease in mortality, compared to the other dwellings. It is important to note that the tested surfaces in the two first dwellings were natural wood, while in the third case the wood was painted with oil base paint. The overal results obtained confirm the prolonged residual activity of pyrethroïds on wood surfaces.

The impact of insecticide application on the domiciliary infestation index (DII) of $L u$. longipalpis is illustrated in Fig. 2.

In intradomiciliar position, the DII was equal to zero for the first two months following insecticide spraying by both methods used. Howewer, the vector presence started to be found since the fourth month after treatment, with CDC light trap.

In peridomiciliar situation, there was no influence of insecticide spraying observed on the occurrence of Lu. longipalpis, as shown on Fig. 2.

\section{DISCUSSION}

The residual effects of pyrethroïd insecticides reported in the literature are variable according to formulations, doses used, types of surfaces tested and species of insects exposed.

Mutinga et al. (1993) reported that mortality rates of Phlebotomus martini, exposed to cotton cloths impregnated with $0.5 \mathrm{mg}$ ai. $/ \mathrm{m}^{2}$ permethrin under laboratory conditions were $76.8 \%$ and $48.5 \%$ respectively, six and nine months after treatment. Morsy et al. (1993) showed a positive relation betwen exposition time of $P$. papatasi on a plastered cement wall treated with permethrin, and the mortality rates obtained; 75 days after treatment, the mortality rates were $0 \%, 17.5 \%, 26 \%, 41.1 \%$ and $51.9 \%$ for exposition times of 5, 10, 15, 20 and $30 \mathrm{~min}$ respectively.
In Colombia, Alexander et al. (1995) found that the use of mosquito-bednets and curtains, impregnated with deltamethrin $\left(26 \mathrm{mg}\right.$ a.i. $\left./ \mathrm{m}^{2}\right)$, reduced the nuisance due to three sand fly species.

Falcão et al. (1991) evaluated the efficacy of deltamethrin $\left(25 \mathrm{mg}\right.$ a.i. $\left./ \mathrm{m}^{2}\right)$ on various sand fly species in an area endemic for cutaneous leishmaniasis, and evaluated the residual effect of this product. They concluded that deltamethrin application reduced the sand fly populations to $50 \%$ and that the mortality rates of $\mathrm{Lu}$. intermedia were $100 \%$ when exposed to the surface ten months after treatment on a wall of concrete and lime painted.

In the State of Paraíba we carried out various series of field assays, in three localities of a VL endemic area. The first assay occurred nine months after treatment with cipermethrin $\left(125 \mathrm{mg}\right.$ a.i. $\left./ \mathrm{m}^{2}\right)$ and the two others five and six months after treatment with deltamethrin $\left(25 \mathrm{mg}\right.$ a.i. $\left./ \mathrm{m}^{2}\right)$. In all these assays, the mortality rates of Lu. longipalpis were particularity low, even reaching zero (Passerat de Silans 1991). The residual activity of the insecticide was only satisfactory when the treated surface was wood, where $100 \%$ mortality rates were observed with both insecticides.

Here, the results according to dwelling surface, seemed to show that cypermethrin efficacy was higher in houses with rought adobe without plastering; however it must be noted that the house studied was inhabited by a single old man, an important fact which may have contributed to the preservation of the insecticide on the wall.

The preliminary results of entomological investigations using aspirators and light traps confirm that residual insecticide applications have no effect on the overal density of peridomiciliar $L u$. 


\section{Samples collected with mouth aspirator}

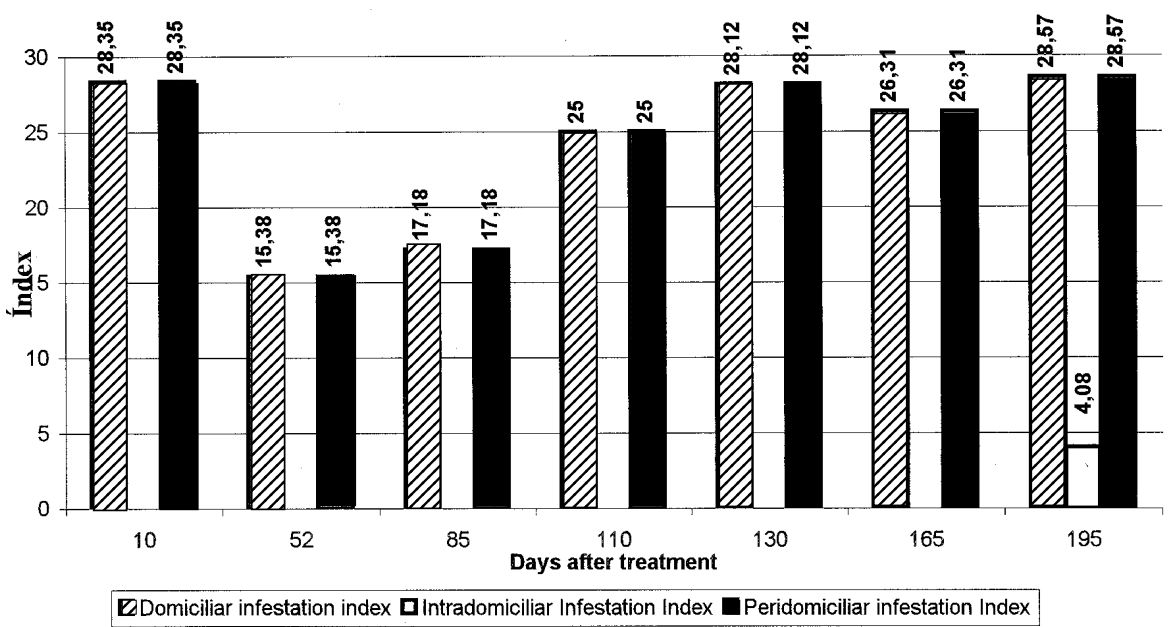

Samples collected with CDC light trap

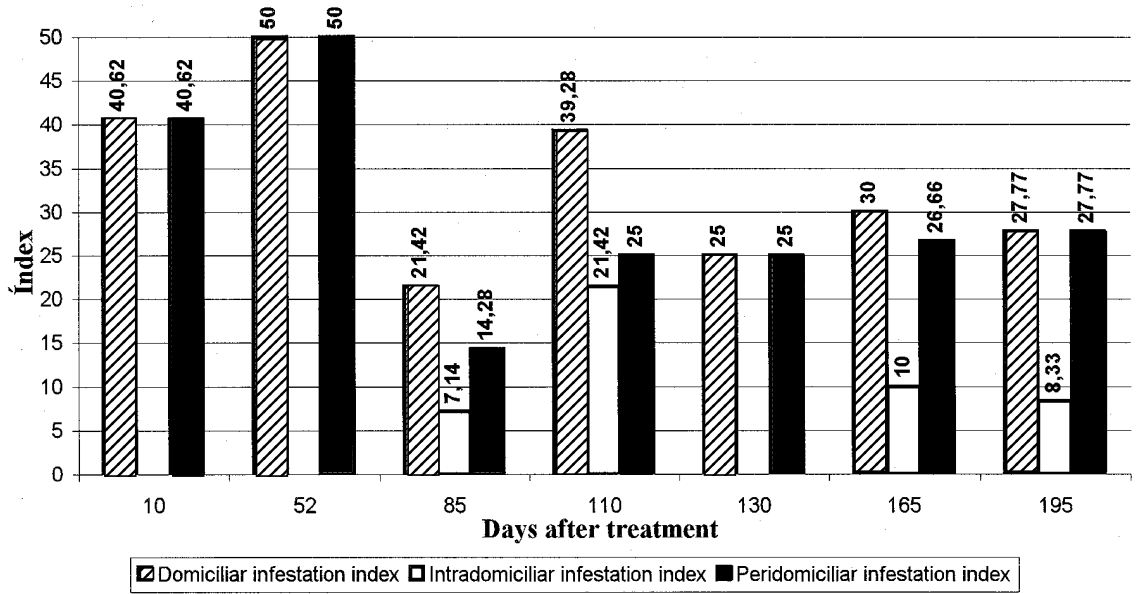

Fig. 2 : infestation indices of Lutzomyia longipalpis (in \%) found in Caxitu after treatment with insecticide cypermethrin, according to place and collection type.

longipalpis populations. However the very small number of vectors inside the dwellings for the first three months after treatment, is probably due to the repelence to the insecticide.

\section{ACKNOWLEDGEMENTS}

To the entomological field team of FNS/CR of Paraíba, and especially Juraci de Lima Flor and Luiz Antonio de Almeida, for excellent technical collaboration.

\section{REFERENCES}

Alexander B, Usma MC, Cadena H, Quesada BL, Solarte Y, Roa W, Travi BL 1995. Evaluation of deltamethrin impregnated bednets and curtains against phlebotomine sandflies in Valle del Cauca, Colombia. Med Vet Entomol 9: 279-283.

Büttiker W 1980. Effect of ground and aerial insecticide. Application on urban phlebotomine sandfly populations in Saudi Arabia, p. 427-439. In HCW Witmer \& W Buttiker (eds), Fauna of Saudi Arabia, Riyadh, Saudi Arabia.

Coradetti A 1968. Phlebotomus control in the Mediterranean and Middle East area. Ann Is Super Sanita 4: 705-708.

Falcão AL, Falcão AR, Pinto CT, Gontijo CMF, Falqueto A 1991. Effect of deltamethrin spraying on the sandfly populations in a focus of American Cutaneous Leishmaniasis. Mem Inst Oswaldo Cruz 86: 399404. 
Kaushal K, Singh K, Das RK, Rahman SJ, Sharma SK 1995. Laboratory and field observations on the vector sandfly Phlebotomus argentipes in India. WHO/ LEISH/95 36, 7 pp.

Lane RP 1990. Contribution of sandfly control to leishmaniasis control. Ann Soc Belge Med Trop 71 (Suppl 1): $65-74$.

Le Pont F, Mariscal-Padilla J, Desjeux P, Richard A, Mouchet J 1989. Impact de pulverisation de deltamethrine dans la leishmaniose de Bolivie. Ann Soc Belge Med Trop 69: 223-232.

Morsy TA, Aboul-Ela RG, El-Gozamy BMR, Salama MMM, Ragreb DA 1993. Residual effects of four insecticides applied for indor control of Phlebotomus papatasi (Scopoli). J Egypt Soc Parasitol 23: 485-492.

Mukhopadhyay AK, Saxena NBL, Narasimham MVVL 1992. Susceptibility status of Phlebotomus argentipes to D.D.T. in some Kala-azar endemic districts of Bihar, India. WHO/CTD/VBC/92 31, 6 pp.

Mutinga MJ, Kamau CC 1986. Investigations on the epidemiology of leishmaniasis in Kenya. II. The breeding sites of phlebotomine sandflies in Marigat, Baringo District, Kenya. Insect Sci Appl 7: 37-44.

Mutinga MJ, Basimike M, Mutero, Ngindu AM 1992. The use of permethrin-impregnated wall cloth (Mbu- cloth) for control of vectors of malaria and leishmaniasis in Kenya. II Effect on phlebotomine sandfly populations. Insect Sci Appl 13: 163-172.

Mutinga MJ, Remapurka DU, Wachira DW, Basimike M, Mutero CU 1993. A bioassay to evaluate the efficacy of permethrin-impregnated screens used against phlebotomine sandflies in Baringo district of Kenya. East Afr Med J 70: 168-170.

Oliveira-Filho AM, Melo MTV, 1994. Vectors control importance on leishmaniasis transmission. Mem Inst Oswaldo Cruz 89: 451-456.

Passerat de Silans LNM 1991. Relatório de resultado de prova biológica de parede, realizada com flebotomíneos adultos em superfícies borrifadas com inseticidas do grupo piretroíde. Diretoria Regional da SUCAM, Paraíba, 20 pp.

Passerat de Silans LNM, Dedet JP 1998. Evaluation of residual effect of pyrethroïd insecticides on the phlebotomine sandfly Lutzomyia longipalpis in the State of Paraíba, Brazil. Mem Inst Oswaldo Cruz (submitted).

WHO 1970. Resistencia a los insecticidas y lucha contra los vectores. Informes tecnicos 443, $307 \mathrm{pp}$.

Xiong Guan-Hua, Jin Chang FA 1987. Studies on deltamethrin in the control of periwild Phlebotomus chinensis. Chin J Parasitol Parasit Disease 5:176179. 